\title{
Geochemical conditions of oil and gas potential of the South Caspian basin on the basis of pyrolytic studies of mud volcanoes
}

\author{
Rustam Mustaev ${ }^{1, *}$, Javidan Ismailov $^{2}$, and Uliana Serikova ${ }^{1}$ \\ ${ }^{1}$ Russian State Geological Prospecting University, Department of geology and exploration of \\ hydrocarbon deposits, 23 Miklouho-Maclay, Moscow, Russia \\ ${ }^{2}$ Gubkin State University of Oil and Gas, 65 Leninsky Prospekt, Moscow, Russia
}

\begin{abstract}
This paper provides the results of geochemical studies with products of mud volcanoes conducted for a purpose of evaluating the generative potential of the South-Caspian basin. The kerogen types have been identified for different stratigraphic intervals and stages of the organic matter (OM) thermal maturity have been determined. A correlation has been established between the generative potential and the basin deposition and subsidence rate.
\end{abstract}

There is no analog in the world to the South-Caspian oil and gas basin in terms of the number of mud volcanoes and their diversity. Over 400 mud-volcano buildups are concentrated there, which is a quarter of the world count. This region also displays active mud volcano behavior, which is accompanied by ejection of a large volume of rock fragments and blocks.

Each mud volcano may be treated as a natural well that delivers rock fragments to the surface from the entire feed channel. The region of the South-Caspian basin is built by a tremendous thickness $(25-30 \mathrm{~km})$ of Mesozoic-Cenozoic sediments and represents a unique opportunity for a depth study of Earth. The origin of mud volcanoes is often connected with oil and gas fields [1]. Large oil and gas-condensate fields have been discovered in other mud volcano areas (Lokbatan, Garadag, Neftyanye Kamni [«Oil Rocks»], Mishovdag, etc.).

For a purpose of evaluating the generative potential of the Mesozoic-Cenozoic complex in the South-Caspian depression, in the geochemical laboratory studies have been conducted of 69 rock samples from 22 mud volcanoes. The volcanoes are located on the Absheron Peninsula, in the Shamakhy-Gobustan area, Lower Kura area, as well as the Caucasus Major (Fig.1). Also, micro-oil samples from mud volcanoes Lokbatan, Chapylmysh and Gushchu have been studied.

\footnotetext{
* Corresponding author: r.mustaev@mail.ru
} 


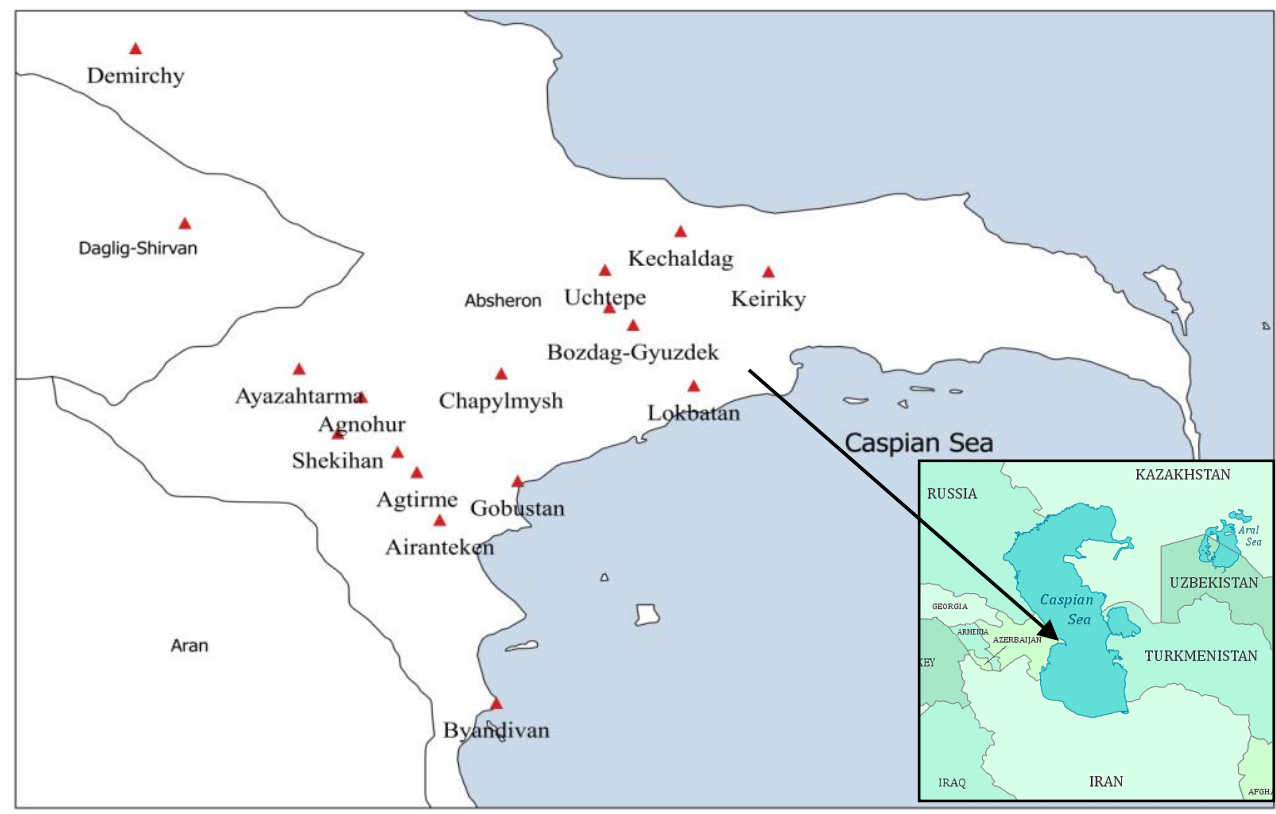

Fig. 1. Location map of the studied Azerbaijan mud volcanoes.

The samples were studied using pyrolysis with Rock-Eval equipment. This enabled the determination of a spectrum of parameters describing qualitative and quantitative features of the rock OM. The parameters included: total organic carbon (TOC), realized $\left(\mathrm{S}_{1}\right)$ and residual rock generative potential $\left(\mathrm{S}_{2}\right)$, oxygen and hydrogen indices (OI and HI), temperature of maximum hydrocarbon yield at pyrolysis $\left(\mathrm{T}_{\max }\right)$, productivity index $(\mathrm{PI})$, etc.

Genetic and catagenetic characteristics of the organic matter are illustrated by various correlation diagrams for such pyrolytic parameters as $\mathrm{HI}, \mathrm{OI}, \mathrm{S} 1+\mathrm{S} 2, \mathrm{~T}_{\max }^{\circ}, \mathrm{TOC}$, etc. One such diagram is a correlation diagram of the hydrogen index (HI) vs. $\mathrm{T}_{\max }^{\circ}$. This diagram is in essence a modified Van-Krevelen diagram. It provides the opportunity to identify kerogen fields of different OM types as well as following their catagenetic evolution.

The modified Van-Krevelen diagram (Fig. 2a) enabled a classification of the kerogen type in samples:

$>$ The Pliocene and Miocene sediments are dominated by type III kerogen (mostly mud volcanoes of the Absheron Peninsula);

$>$ The Oligocene and Eocene sediments are dominated by type II and III kerogen (mostly mud volcanoes of the Shamakhy-Godustan area); in several Oligocene samples type I kerogen was discovered;

$>$ The Jurassic sediments are dominated by type III kerogen (mostly mud volcanoes of the Caucasus Major);

$>$ In the Cretaceous sediments the OM is represented by type IV kerogen and is positioned in the non-generative area (mostly mud volcanoes of the Caucasus Major).

Low oxygen index values (less than $30 \mathrm{mg} \mathrm{CO} / \mathrm{g}$ of TOC) in most samples indicates the low extent of oxidation.

A dual diagram of $\mathrm{HI}$ and $\mathrm{T}_{\max }$ (Fig. 2b) shows that the samples capable of generating hydrocarbons have $\mathrm{T}_{\max } 435-468^{\circ} \mathrm{C}$. 


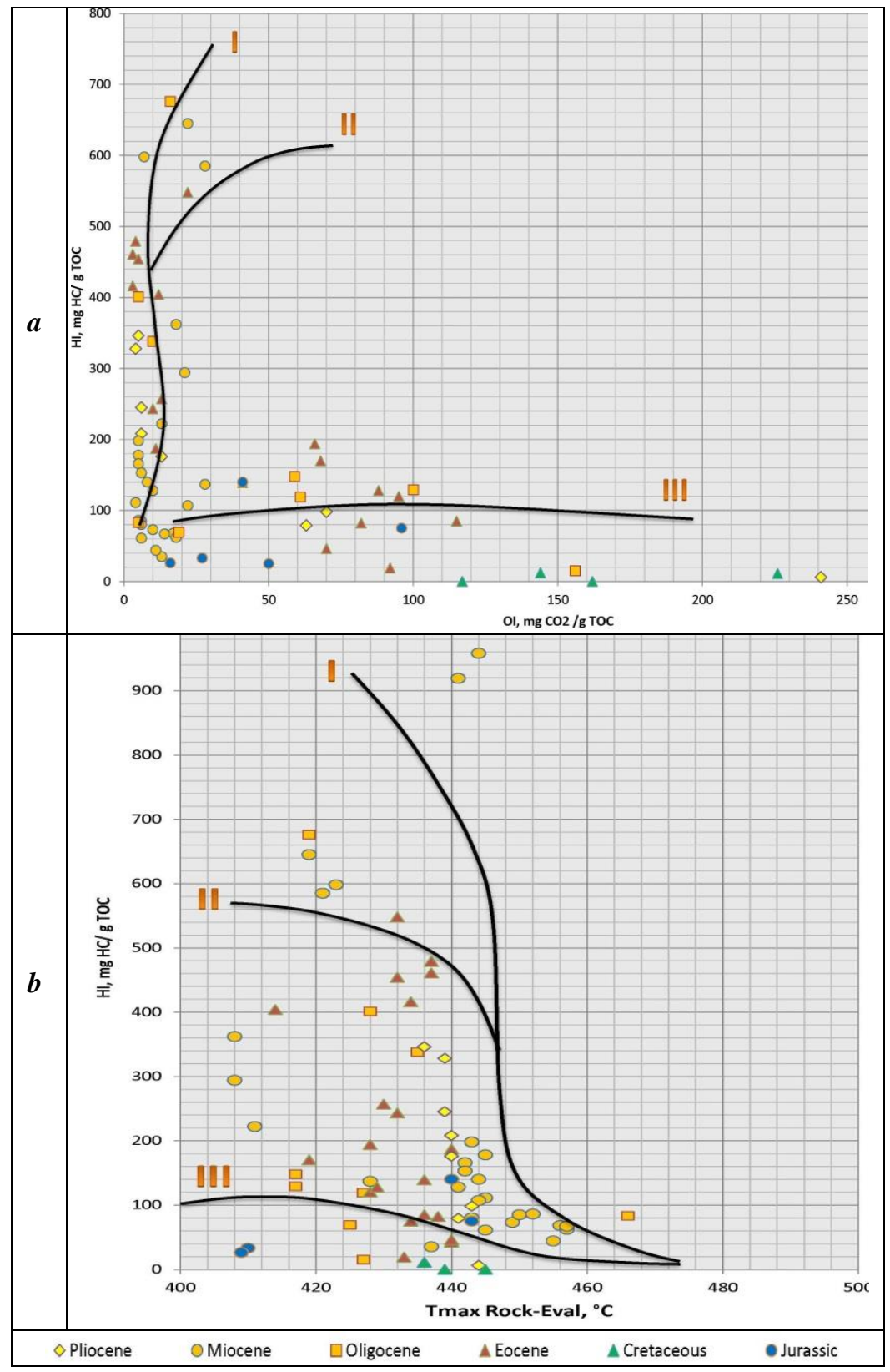

Fig. 2. Modified Van-Krevelen diagrams: hydrogen index HI vs. oxygen index OI (a) hydrogen index $\mathrm{HI}$ vs. maximum pyrolysis temperature $\mathrm{T}_{\max }(\mathrm{b})$.

According to J. Espitalier and K. Peters [2-4], reservoirs containing liquid oil or high concentrations of mobile bitumoid have anomalously low pyrolysis temperatures $T_{\max }$.

In the correlation diagram $\mathrm{T}_{\max }$ vs. PI (Fig. 3a) the points belonging to samples of different age and stage of OM thermal maturity (regarding the capability for oil and gas generation), are distributed by their stratigraphic association:

$>$ The Pliocene sediments in the $436-444^{\circ} \mathrm{C}$ area - early maturity stage;

$>$ The Miocene sediments in the $440-458^{\circ} \mathrm{C}$ area - between the peak of oil generation and the late maturity stage; 
The Oligocene sediments in the $416-438^{\circ} \mathrm{C}$ area - the early maturity stage;

$>$ The Eocene sediments in the $432-440^{\circ} \mathrm{C}$ area - the early maturity stage;

$>$ The Cretaceous sediments in the $434-443^{\circ} \mathrm{C}$ area - the early maturity stage;

$>$ The Jurassic sediments around $410-445^{\circ} \mathrm{C}-$ between immature and the early maturation stage.

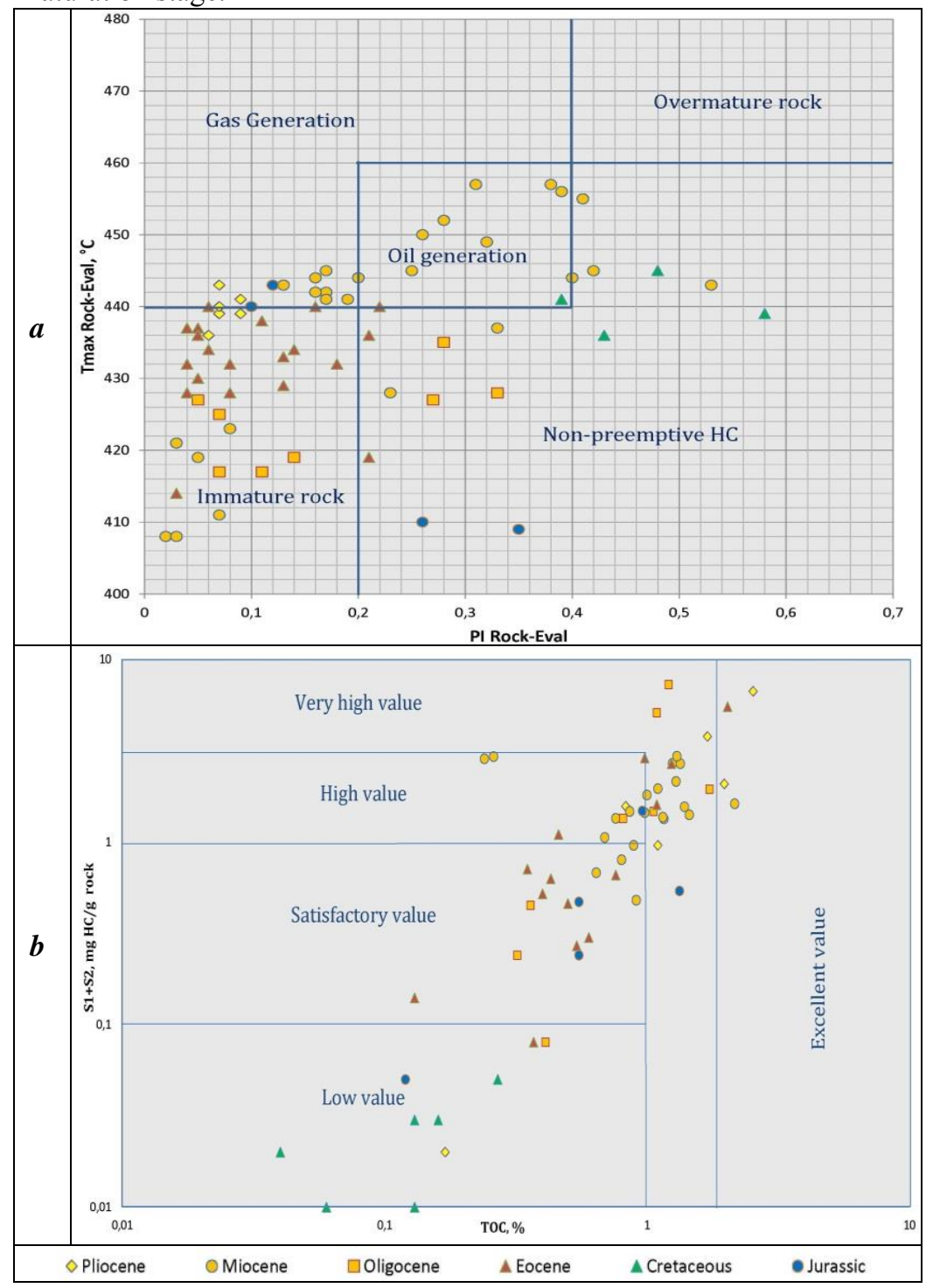

Fig. 3. Correlation $\mathrm{T}_{\max }$ vs. PI (a) and ( $\left.\mathrm{S} 1+\mathrm{S} 2\right)$ vs. TOC (b).

Overall, low $T_{\max }$ values emphasized the migration nature of the bitumoid [5-8]. At temperatures that low, the extent of OM catagenetic maturity is quite low [9-13]. Despite an insignificant $\mathrm{OM}$ maturity extent, it is possible that hydrocarbon generation is already occurring. It is supported by the elevated content of $\mathrm{S}_{1}$ in the samples. For mature samples of the Miocene sediments in the value range of the pyrolytic parameter $\mathrm{T}_{\max }-440-458^{\circ} \mathrm{C}$, the OM catagenetic permutation corresponds with the middle and completing stage of the «oil window» MK2-MK3. This is also supported by an increase of the productivity index up to 0.44 . 
The correlation diagram of the total (oil and kerogen) potential $\left(\mathrm{S}_{1}+\mathrm{S}_{2}\right)$ vs. TOC (Fig.3b) shows wide variability. These stratigraphic associations are identified:

$>$ The Pliocene sediments with very high and outstanding generative potential;

$>$ The Miocene and Oligocene with satisfactory to very high generative potential;

$>$ The Eocene sediments with mostly satisfactory generative potential;

$>$ The Cretaceous sediments with low generative properties (both according to $\mathrm{S} 1+\mathrm{S} 2$ and $\mathrm{C}_{\text {org }}$ );

$>$ The Jurassic sediments with widely variable generative properties between satisfactory to very high.

\section{Conclusions}

A pyrolytic study of 69 rock samples from 22 mud volcano ejecta in the Apsheron Peninsula, which describe the entire stratigraphic section of the South-Caspian Basin, suggested the following conclusions:

- The South-Caspian basin is a polyfocal basin. Within it are identified several stratigraphically separated autonomous generation foci: Aalenian-Bajocian (Middle Jurassic), Valanginian (Lower Cretaceous), Laleogene-Lower Miocene (mostly Oligocene-Lowe Miocene, i.e., Maykopian), Diatomaceous (Middle-Upper Miocene) and Kalin (lower part of the Lower Pliocene, i.e., Productive Series PT).

- Kerogen types in various stratigraphic intervals were established, organic matter thermal maturity stages were determined and the source rock generative potential was correlated with the total organic carbon content.

This study was supported by the Ministry of Education and Science of the Russian Federation (state contract no. 10.6569.2017/BCh).

\section{References}

1. I. Guliev, B, Panahi, Geo-Marine Letters, 24, 3, 169, (2004)

2. J. Espitali; B. Durand; J. C. Roussel; C. Souron, Rev. Inst. Fr. Pétr., 1973, 28, 1, 37 (1973)

3. R. Pelet, Rev. d'Institut Francais du Pétrole, 40, 5, 551, (1985)

4. K.E. Peters, AAPG Bulletin, 70, 3, 318, (1986)

5. V.Yu. Kerimov, A.V. Osipov, E.A. Lavrenova, Neftyanoe khozyaystvo - Oil Industry, 4, 33 (2014)

6. V.Yu. Kerimov, R.N. Mustaev, S.S. Dmitrievsky, V.A. Zaitsev, Neftyanoe khozyaystvo - Oil Industry, 9, 18 (2016)

7. A.L. Lapidus, V.Y. Kerimov, R.N. Mustaev, E.M. Movsumzade, M.V. Zakharchenko, Oil Shale. 35(2), 113, (2018)

8. V.Y. Kerimov, M.Z. Rachinsky, R.N. Mustaev, A.V. Osipov, Doklady Earth Sciences, 476, 1, 1066 (2017)

9. V.Yu. Kerimov, R.N. Mustaev, N.Sh.Yandarbiev, E.M. Movsumzade Oriental J.Chem. 33, 2, 879 (2017)

10. R.N. Mustaev, W.N. Hai, V.Y. Kerimov, E.A. Leonova, Geomodel 2015 - 17th Scientific-Practical Conference on Oil and Gas Geological Exploration and Development (2015)

11. I.S. Guliyev, V.Y. Kerimov, A.V. Osipov, R.N. Mustaev, SOCAR Proceedings, 1, 4, (2017) 
12. V.Y. Kerimov, A.V. Bondarev, A.V. Osipov, S.G. Serov, Neftyanoe khozyaystvo - Oil Industry, 5, 39 (2015)

13. M.Z. Rachinsky, V.Y. Kerimov, Scrivener Publishing Wiley, 640, (2015) 